\title{
SCALE-UP STUDY ON THE SUPERCRITICAL CARBON DIOXIDE STERILISATION OF OIL PALM FRESH FRUIT BUNCH
}

\author{
TENGKU NORSALWANI, T L*; MD SOHRAB HOSSAIN*; ABDUL KHALIL, H P S*; FATEHAH \\ M OMAR ${ }^{* *}$; AZHAR M EASA*; ASMAH M SOFIAN ${ }^{*}$ and MOHD OMAR, A K*
}

\begin{abstract}
Existing steam sterilisation method of oil palm fresh fruit bunch (OP-FFB) requires huge quantities of water and about 30\%-60\% of the water results in palm oil mill effluent (POME). In order to circumvent the perennial POME generation problem, it requires a waterless sterilisation system of OP-FFB. The present study was conducted to determine the sterilisation efficiency of OP-FFB using a pilot scale supercritical carbon dioxide $\left(\mathrm{SC}-\mathrm{CO}_{2}\right)$ technology. The sterilisation efficiency was evaluated based on the inactivation of Bacillus spp. and Aspergillus spp. in OP-FFB with varying $S C-\mathrm{CO}_{2}$ pressure (10-30 $\mathrm{MPa}$ ), temperature $\left(40^{\circ} \mathrm{C}-80^{\circ} \mathrm{C}\right)$ and treatment time (15-90 min). Complete inactivation of the microorganisms in OP-FFB was obtained after 45-90 min at treatment range of $10-30 \mathrm{MPa}$ and $40^{\circ} \mathrm{C}-80^{\circ} \mathrm{C}$. The findings of the present study reveal that the $\mathrm{SC}-\mathrm{CO}_{2}$ sterilisation is a conceivable technology to be used in OP-FFB sterilisation, replacing the current water steam sterilisation technology.
\end{abstract}

Keywords: oil palm fruit bunch, supercritical carbon dioxide, steam sterilisation, sterilisation.

Date received: 19 October 2018; Sent for revision: 24 December 2018; Accepted: 20 May 2019.

\section{INTRODUCTION}

Sterilisation of oil palm fresh fruits bunch (OP-FFB) is an important stage for palm oil production from oil palm fruits. The sterilisation process functions in supplying heat for fruits softening and easy detachment of the fruits from fresh fruit bunch (FFB) stalks and inactivate enzymes that are responsible for the rise of free fatty acids (FFA) in the oil (Vincent et al., 2014). Numerous sterilisation methods have been utilised in OP-FFB sterilisation, including steam sterilisation (Junaidah et al., 2015), oven dry heating (Abdul Hadi et al., 2012), radio frequency (Liu et al., 2015) and microwave treatment (Sarah and

\footnotetext{
* School of Industrial Technology,

Universiti Sains Malaysia,

11800 Minden, Pulau Pinang, Malaysia.

E-mail: sohrab@usm.my

** School of Civil Engineering,

Nibong Tebal Campus,

Universiti Sains Malaysia,

14300 Nibong Tebal, Pulau Pinang, Malaysia.
}

Taib, 2013). Among these technologies, the steam sterilisation is utilised by palm oil industries since other technologies are still in development at pilot scales in order to test their respective capabilities to fulfill the requirements for sterilisation and can only accommodate small amounts of the fruitlets to be sterilised at one time (Vincent et al., 2014; Lai et al., 2012). However, steam sterilisation process requires large amounts of water in OP-FFB sterilisation, resulting in huge amounts of palm oil mill effluent (POME) (Vincent et al., 2014). POME is a thick brownish liquid that contains high biological oxygen demand (BOD), chemical oxygen demand (COD), suspended solid (SS) and thereby treated as a highly polluted wastewater, which requires effective treatment of POME to eliminate impurities prior to discharge into the nearest watercourse (Vincent et al., 2014; Choong et al., 2018). Therefore, palm oil industries are looking for an effective alternative technology to steam sterilisation to minimise wastewater generation. Besides, the level of FFA present in the palm oil extracted from steam sterilised OP-FFB has raised particular concern to the palm oil producers (Mohd Omar et al., 2017). This is 
because of the fact that the FFA present in palm oil can be oxidised, which subsequently reduce palm oil quality and increase in rancidity (Mohd Omar et al., 2018; Man et al., 1999).

The presence of FFA in palm oil is directly attributed to the action of lipase (triacylglycerol acylhydrolase) (Nanssou Kouteu et al., 2016; Taher et al., 2011). Generally, the OP-FFB contains active endogenous lipases and the high oil content in the mesocarp of oil palm fruit makes it a rich substrate for lipase activity (Taher et al., 2011). Benoit Constant et al. (2017) observed the lipase activity in palm oil because of the presence of lipophilic microorganisms in OP-FFB. Banani et al. (2015) stated that microorganisms secrete lipase during metabolism, which is subsequently activated during the hydrolysis of palm oil triglycerides thus increasing the FFA content. However, Patil et al. (2011) reported that the major portion of lipase (about $80 \%$ ) is produced by microorganisms (bacteria and fungi), and the rest of the lipases are produced by plants and animals. Several investigations have been conducted to determine microorganisms present in OP-FFB responsible for producing lipase enzymes in OP-FFB. Tagoe et al. (2012) detected the presence of bacteria and fungi in oil palm fruits and extracted palm oil using Terminal Restriction Fragment analysis and polymerase chain reaction (PCR) amplifications methods. Khan et al. (2005) detected lipolytic fungi on oil palm spikelets such as Aspergillus spp., Mucor spp. and Penicillium spp.

Steam sterilisation is unable to completely denature the lipase enzyme and inactivate pathogens present in OP-FFB, as evinced by studies reporting lipophilic activity and the presence of microorganisms in crude palm oil (Ohimain et al., 2013) and refined palm oil (Tagoe et al., 2012). Ohimain et al. (2013) have also raised concern on the conventional steam sterilisation method of OP-FFB due to the presence of lipolytic microorganisms in extracted crude palm oil (CPO). Similarly, Hossain et al. $(2015 \mathrm{a}, \mathrm{b})$ observed that steam sterilisation is unable to completely kill the microorganisms in clinical solid waste due to incomplete denaturation of cellular proteins and enzymes. Thus, there is a need to find alternative sterilisation methods for effective denaturation of lipase and microorganisms present in OP-FFB.

The $\mathrm{SC}-\mathrm{CO}_{2}$ sterilisation has been demonstrated to be an effective sterilisation method and has been widely utilised in various industrial fields (Balestrini et al., 2016; Dillow et al., 1999; Hossain et al., 2016b; 2011). Due to the relatively low operating temperatures and moderate operating pressures, the $\mathrm{SC}-\mathrm{CO}_{2}$ sterilisation technology has attracted attention to sterilise heat sensitive materials (Hossain et al., 2015a; Splimbergo et al., 2003). Moreover, the SC$\mathrm{CO}_{2}$ sterilisation technology has been proven to be very effective in the inactivation of microorganisms and deactivation of enzymes and proteins (Kim et al., 2007; Hossain et al., 2016a). In recent years, SC$\mathrm{CO}_{2}$ has gained attention in the food industry for the inactivation of enzymatic activity, as the presence of the active enzyme in food products results in unpleasant change and degrades their quality (Hu et al., 2013; Wimmer and Zarevúcka, 2010). Balaban et al. (1991) investigated the inactivation of pectinesterase in orange juice using $\mathrm{SC}-\mathrm{CO}_{2}$ and determined the juice quality and sensory attributes, where the sensory evaluations showed that the colour and cloudiness of treated juice were better than in untreated juice. Furthermore, the flavour and aroma of the orange juice were not affected by the sterilisation (Balaban et al., 1991). The oil palm lipase is located in the mesocarp of the oil palm fruits with an optimal activity at pH 7.5 (Ngando Ebongue et al., 2006). Therefore, it can be denatured by lowering the $\mathrm{pH}$ to an acidic environment. Thus, it bears considerable interest to adopt $\mathrm{SC}-\mathrm{CO}_{2}$ sterilisation technology to sterilise OP-FFB in order to effectively inactivate lipase and microorganisms present in OPFFB, since $\mathrm{SC}-\mathrm{CO}_{2}$ reacts with microorganisms by lowering the $\mathrm{pH}$ below 5.0 with the formation and dissociation of $\mathrm{H}_{2} \mathrm{CO}_{3}$ (Splimbergo et al., 2003).

In a recent study, Mohd Omar et al. (2017) studied the possibility of applying the SC- $\mathrm{CO}_{2}$ in OPEFB sterilisation at a laboratory scale, wherein the efficiency of the $\mathrm{SC}-\mathrm{CO}_{2}$ sterilisation was determined based on the microbial inactivation in contaminated OP-EFB and stripping oil palm fruits from OP-FFB. It was found that the $\mathrm{SC}-\mathrm{CO}_{2}$ sterilisation was able to achieve complete inactivation of microorganisms at temperature of $80^{\circ} \mathrm{C}$ and pressure of $10 \mathrm{MPa}$ at 60 min treatment time. They suggested to conduct a further study on the $\mathrm{SC}-\mathrm{CO}_{2}$ sterilisation of OPFFB in a large scale. Therefore, the present study was conducted to sterilise OP-FFB using $\mathrm{SC}-\mathrm{CO}_{2}$ in a pilot scale. The influence $\mathrm{SC}-\mathrm{CO}_{2}$ sterilisation of OP-FFB was determined based on the inactivation efficiency of Bacillus spp. (bacteria) and Aspergillus spp. (fungi) with varying $\mathrm{SC}-\mathrm{CO}_{2}$ pressure, temperature and treatment time. The finding of the present study will assist to determine the viability of SC- $\mathrm{CO}_{2}$ sterilisation as an alternative technology to sterilise oil palm fruits at industrial scale.

\section{EXPERIMENTAL}

\section{Sample Collection and Preparations}

Ripe OP-FFB was randomly collected from a pile of recently harvested fruits (within a day) to represent actual fruits from the local palm oil mill in Malaysia. Each bunch was cut into 20-30 cm length in order to separate the bunch into smaller spikelets using a mechanical cutter. The spikelets were then stored in the refrigerator at $4^{\circ} \mathrm{C}$ until further use. 
The microorganisms used in the present study were Bacillus spp. (vegetative bacteria) and Aspergillus spp. (fungi), which were previously isolated from the OPEFB (Mohd Omar et al., 2017). The isolated Bacillus spp. and Aspergillus spp. were re-cultured in nutrient agar media and potato dextrose agar media, respectively, and incubated to obtain fresh culture. A single isolated colony of Bacillus spp. and Aspergillus spp. was then transferred into nutrient broth and potato dextrose broth; incubated at $37^{\circ} \mathrm{C}$ for $24 \mathrm{hr}$ and at $28^{\circ} \mathrm{C}$ for $120 \mathrm{hr}$, respectively (Sanders, 2012; Mohd Omar et al., 2017). Subsequently, bacterial broth $(200 \mathrm{ml})$ and fungal broth $(200 \mathrm{ml})$ were used to contaminate about $2 \mathrm{~kg}$ of OP-FFB, individually, by adding the broth in a drop wise manner. Later, the contaminated OP-FFB was taken into the SC$\mathrm{CO}_{2}$ reactor (10 litres) for sterilisation. The same step was repeated using autoclaved steriliser.

\section{Supercritical Carbon Dioxide Sterilisation}

The influence of the SC- $\mathrm{CO}_{2}$ sterilisation of OPFFB was conducted using a $\mathrm{SC}-\mathrm{CO}_{2}$ reactor system with a volume of 10 litre (Nantong Wisdom, China), as shown in Figure 1. The sensitivity of Bacillus spp. and Aspergillus spp. to $\mathrm{SC}-\mathrm{CO}_{2}$ sterilisation was evaluated with varying pressure (10-30 $\mathrm{MPa})$, temperature $\left(40^{\circ} \mathrm{C}-80^{\circ} \mathrm{C}\right)$ and treatment time $(15-90$ min). The purified $\mathrm{CO}_{2}$ gas was released into the sterilisation chamber and once the set pressure was achieved, the process was left for a specific duration.
At the end of the sterilisation time, the chamber was depressurised by releasing the gas. The treated OP-FFB were then collected to determine the number of viable colonies. Experiments were performed in triplicate and the results expressed as the mean value \pm standard error.

\section{Autoclave Sterilisation}

Autoclave treatment was carried out using a HiClave autoclave (Hirayama, Japan). The parameters of the treatment were temperature at $121^{\circ} \mathrm{C}$, pressure at $0.1 \mathrm{MPa}$ and duration for 60 min, according to the recommended experimental conditions for autoclave sterilisation by Hossain et al. (2012). The autoclave process was carried out and samples were retrieved from the autoclave after completing the sterilisation process.

\section{Quantification of Viable Colonies}

The viability of studied microorganisms in SC$\mathrm{CO}_{2}$ treated and untreated OP-FFB was determined using pour-plate method. Ten individual oil palm fruits of approximately $100 \mathrm{~g}$ were randomly taken from the oil palm spikelets and immersed in $900 \mathrm{ml}$ sterile distilled water. The flasks were tightly sealed and agitated on the shaker at $100 \mathrm{rpm}$ for $5 \mathrm{~min}$. An eight-fold serial dilution was carried out by initially taking out $1 \mathrm{ml}$ of the contaminated into $9 \mathrm{ml}$ of sterile distilled water, from which $0.1 \mathrm{ml}$ were seeded on

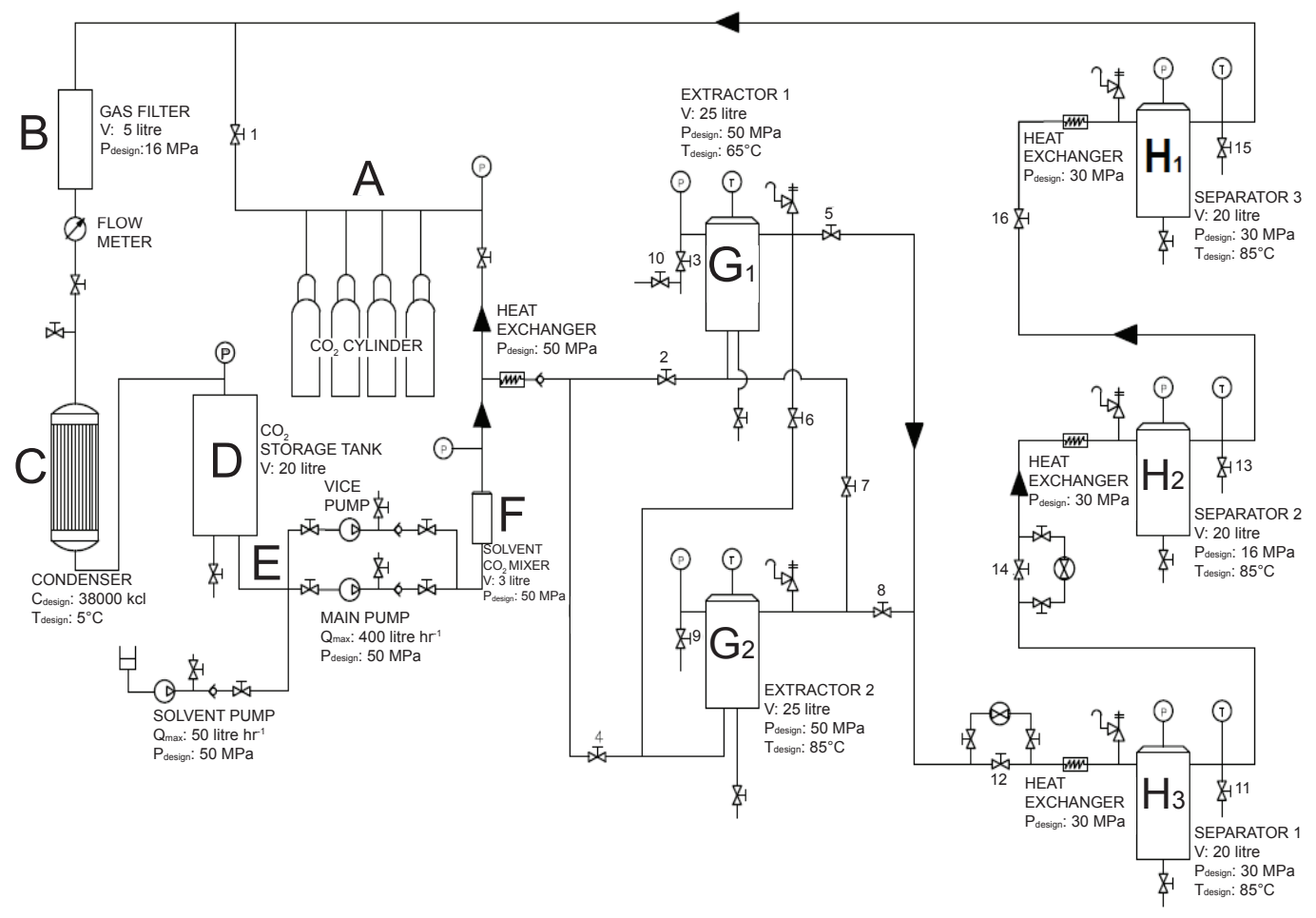

Figure 1. Schematic diagram of pilot scale supercritical carbon dioxide (SC-CO$)_{2}$ ) sterilisation system; $A-C \mathrm{O}_{2}$ tank, $B$ - gas filter, $\mathrm{C}-$ condenser, $\mathrm{D}-\mathrm{CO}_{2}$ storage tank, $E$ - pumps, $F$ - solvent and $\mathrm{CO}_{2}$ mixer, $G-G_{1}$ sterilisation vessel $1, G_{2}$ sterilisation vessel 2, $H-$ separator. 
Petri dishes containing nutrient agar and potato dextrose agar media for bacterial and fungal growth, respectively. The agar was streaked a few times to obtain colonies with uniform growth. The petri plates were sealed using parafilm and incubated at $37^{\circ} \mathrm{C} \pm$ $1^{\circ} \mathrm{C}$ for $24 \mathrm{hr}$ and $28^{\circ} \mathrm{C} \pm 1^{\circ} \mathrm{C}$ for $120 \mathrm{hr}$ for bacteria and fungi, respectively. After the incubation period, the number of viable bacterial of fungal colonies were determined as shown in Equation (1) (Hossain et al., 2013).

$\frac{\mathrm{CFU}}{\mathrm{g}}=\frac{\begin{array}{c}\text { Number of } \\ \text { viable colonies }\end{array}}{\begin{array}{c}\text { Agar plating } \\ \text { Volume }\end{array}} \times \frac{1}{\begin{array}{c}\text { Dilution } \\ \text { factor }\end{array}} \times \frac{\begin{array}{c}\text { Volume of } \\ \text { contaminate }\end{array}}{\text { Mass OPFB }}$

The initial concentration $\left(\log N_{0}\right)$ of Bacillus spp. and Aspergillus spp. were determined to be $5.67 \mathrm{log}$ colony forming unit per gram $\left(\log \mathrm{CFU} \mathrm{g}{ }^{-1}\right)$ and 5.03 $\log \mathrm{CFU} \mathrm{g^{-1 }}$, respectively. The $\log$ reduction of the number of viable colonies per gram of OP-FFB was determined as the number of survival colonies before sterilisation $\left(N_{0}\right)$ to the number of viable colonies after sterilisation $\left(N_{t}\right)$, as shown in Equation (2).

$$
\text { Log reduction }\left(\mathrm{CFU} \mathrm{g}^{-1}\right)=\log \frac{\mathrm{N}_{0}}{\mathrm{~N}_{\mathrm{t}}}
$$

\section{Morphological Alterations of SC- $\mathrm{CO}_{2}$ Sterilised OP-FFB}

Physical changes of the spikelet fruits were observed based on the fruit surface appearance before and after $\mathrm{SC}-\mathrm{CO}_{2}$ treatment. Further, surface morphology of the oil palm mesocarp fibre (OPMF) of $\mathrm{SC}-\mathrm{CO}_{2}$ sterilised OP-FFB was analysed using a field emission scanning electron microscope (FESEM), and compared with the FE-SEM images of OPMF collected from untreated and steam autoclave treated OP-FFB. The OPMF was obtained by cutting treated and untreated OP-FFB manually using a sharp blade with an average length of $20 \mathrm{~mm}$. A piece of OPMF was attached to the FE-SEM stub with a double-sided tape. It was then coated with a thin layer of gold $(\sim 20 \mathrm{~nm})$ in a Sputter Coater Polar SC515 FISONS. The surface of the sample was viewed in a FE-SEM operated at $5.00 \mathrm{kV}$.

\section{RESULTS AND DISCUSSION}

\section{Inactivation of Microorganisms in Oil Palm Fruits Bunch Using SC- $-\mathrm{CO}_{2}$}

The inactivation of microorganisms such as Bacillus spp. and Aspergillus spp. in OP-FFB using $\mathrm{SC}-\mathrm{CO}_{2}$ with varying pressure and temperature as function of treatment time revealed the reduction of viable cells of both microorganisms. Figure 2 shows the viable cell reduction of Bacillus spp. increased with temperature and pressure from $40^{\circ} \mathrm{C}$ to $80^{\circ} \mathrm{C}$ and $10 \mathrm{MPa}$ to $30 \mathrm{MPa}$, respectively. At 10 $\mathrm{MPa}$ pressure, the time required for the complete inactivation (viable cell reduction reached to the maximum at $\log 5.67 \mathrm{CFU} \mathrm{g}^{-1}$ ) of the Bacillus spp. was determined to be $90 \mathrm{~min}$ for $80^{\circ} \mathrm{C}$. It was not able to gain the optimal log reduction of the Bacillus spp. viable cells at $90 \mathrm{~min}$ (maximum treatment time studied) with pressure of $10 \mathrm{MPa}$ and temperature of $40^{\circ} \mathrm{C}$ and $60^{\circ} \mathrm{C}$. It was found that treatment time and temperature required for the complete inactivation of Bacillus spp. at $10 \mathrm{MPa}$ was reduced with further increase of pressure. For instance, the treatment time required for the complete inactivation of Bacillus spp. were $90 \mathrm{~min}, 75 \mathrm{~min}$ and $60 \mathrm{~min}$ at $40^{\circ} \mathrm{C}, 60^{\circ} \mathrm{C}$ and $80^{\circ} \mathrm{C}$, respectively, for $20 \mathrm{MPa}$. The treatment
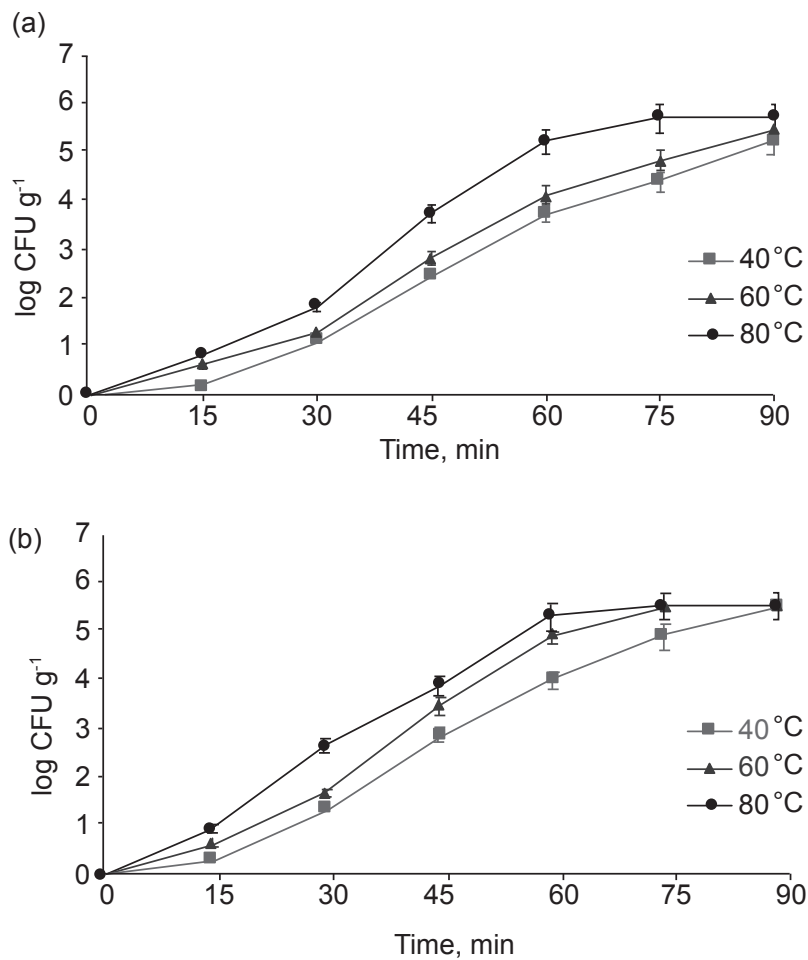

(c)

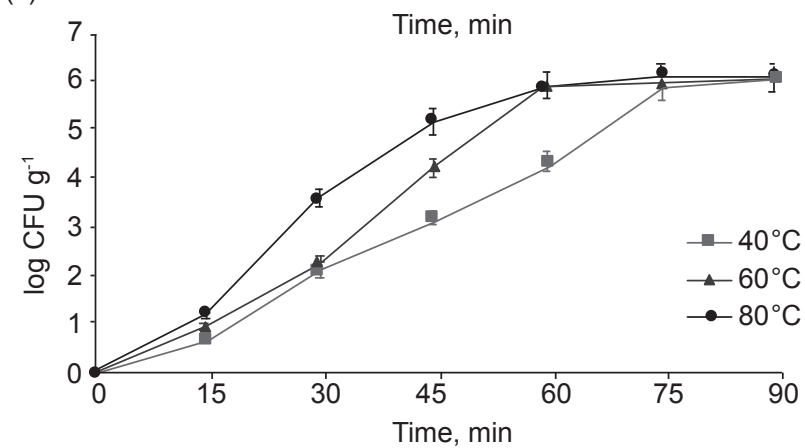

Figure 2. Effect of temperature on the inactivation of Bacillus spp. in oil palm fruits bunch using supercritical carbon dioxide $\left(\mathrm{SC}-\mathrm{CO}_{2}\right)$ at pressure $10 \mathrm{MPa}-30 \mathrm{MPa}$. (a) $10 \mathrm{MPa}$, (b) $20 \mathrm{MPa}$ and (c) $30 \mathrm{MPa}$. 
time further reduced at $30 \mathrm{MPa}$ to $75 \mathrm{~min}$ for $40^{\circ} \mathrm{C}$, $60 \mathrm{~min}$ for $60^{\circ} \mathrm{C}$ and $80^{\circ} \mathrm{C}$.

The log reduction of the viable cells of Aspergillus spp. was determined with varying $\mathrm{SC}-\mathrm{CO}_{2}$ pressure and temperature as a function of time, as presented in Figure 3. It was found that the viable cell reduction increased with increasing temperature from $40^{\circ} \mathrm{C}$ to $80^{\circ} \mathrm{C}$ and pressure from $10 \mathrm{MPa}$ to 30 $\mathrm{MPa}$. The treatment time required for the complete inactivation of Aspergillus spp. in OP-FFB at $10 \mathrm{MPa}$ were $90 \mathrm{~min}, 90 \mathrm{~min}$ and $60 \mathrm{~min}$ for $40^{\circ} \mathrm{C}, 60^{\circ} \mathrm{C}$ and $80^{\circ} \mathrm{C}$, respectively. As the pressure increased the degree of Aspergillus spp. inactivation also increased, which substantially reduced the required treatment time for the complete inactivation of Aspergillus spp. in OP-FFB. The treatment time required for the complete inactivation Aspergillus spp. at $20 \mathrm{MPa}$ were $90 \mathrm{~min}, 60 \mathrm{~min}$ and $60 \mathrm{~min}$ for $40^{\circ} \mathrm{C}, 60^{\circ} \mathrm{C}$ and $80^{\circ} \mathrm{C}$, respectively. The treatment time for the complete inactivation of the Aspergillus spp. were further reduced at $30 \mathrm{MPa}$ to $75 \mathrm{~min}, 60 \mathrm{~min}$ and 45 min at $40^{\circ} \mathrm{C}, 60^{\circ} \mathrm{C}$ and $80^{\circ} \mathrm{C}$, respectively.

(a)
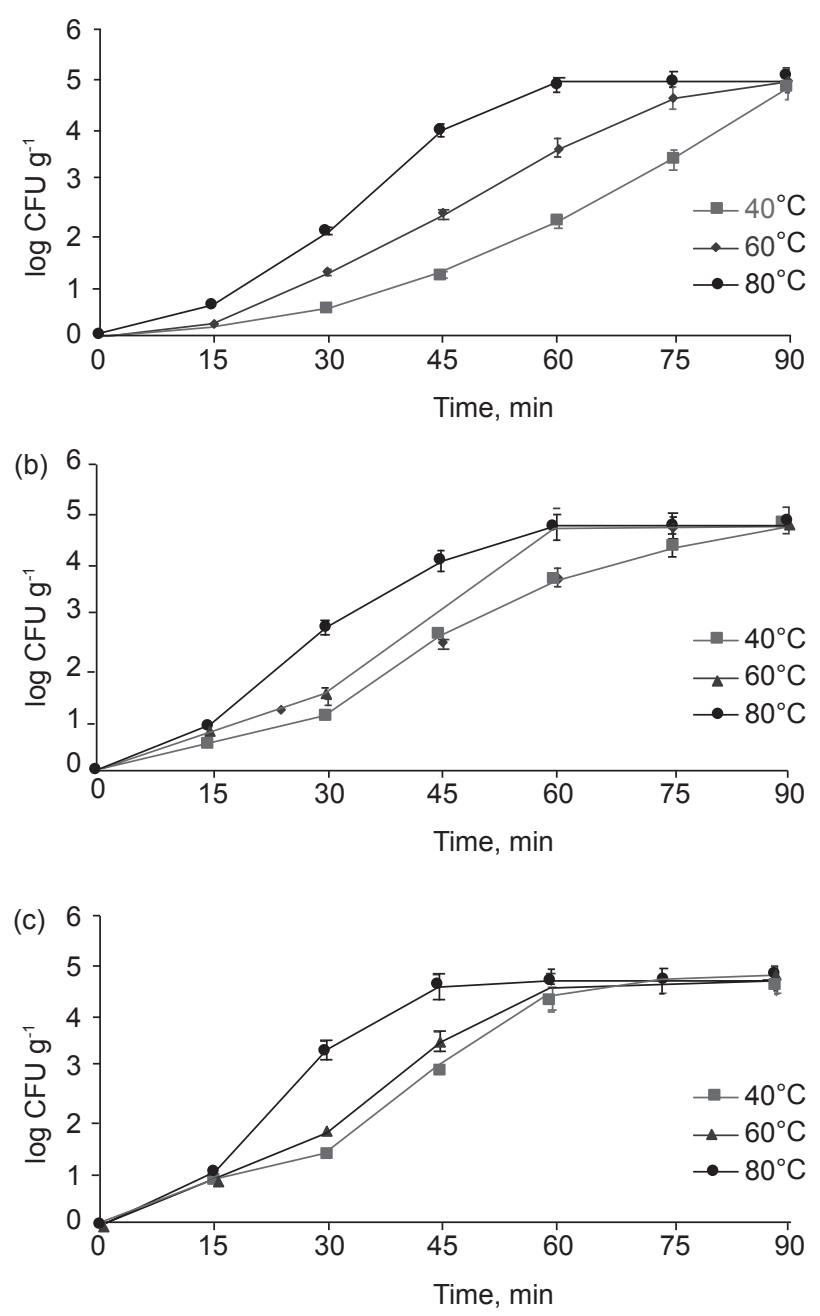

Figure 3. Effect of temperature on the inactivation of Aspergillus spp. in oil palm fruits bunch using supercritical carbon dioxide $\left(\mathrm{SC}-\mathrm{CO}_{2}\right)$ at pressure $10 \mathrm{MPa}-30 \mathrm{MPa}$. (a) $10 \mathrm{MPa}$, (b) $20 \mathrm{MPa}$ and (c) $30 \mathrm{MPa}$.
The inactivation of the microorganisms in OPFFB using $\mathrm{SC}-\mathrm{CO}_{2}$ revealed that the $\mathrm{SC}-\mathrm{CO}_{2}$ is an effective method to sterilise OP-FFB. Both pressure and temperature play important role to inactivate Bacillus spp. and Aspergillus spp. in OP-FFB using $\mathrm{SC}-\mathrm{CO}_{2}$ sterilisation. The pressure enhances the $\mathrm{CO}_{2}$ solubilisation in the moisture present in OP$\mathrm{FFB}$, easing the $\mathrm{CO}_{2}$ penetration to microbial cell. Wherein, an increase of temperature increases diffusivity of $\mathrm{CO}_{2}$, at lower pressure, it required higher temperature and treatment time to reach the complete inactivation (Hossain et al., 2016a). However, the treatment time had the minimal effect on the reduction of microbial colony count at $40^{\circ} \mathrm{C}$ (considered as low temperature). After an hour of $\mathrm{SC}-\mathrm{CO}_{2}$ exposure at $80^{\circ} \mathrm{C}$, more than $1 \log$ reduction of the microbes (90\% inactivation) was attained for both fungi and bacterial under the three applied pressures. The log reduction increased gradually for the first $15 \mathrm{~min}$ and increased rapidly thereafter. The complete inactivation of Bacillus spp. was gained at $10 \mathrm{MPa}, 80^{\circ} \mathrm{C}$ for $75 \mathrm{~min}$. With an increase of pressure and under similar $\mathrm{SC}-\mathrm{CO}_{2}$ temperature, the treatment time further reduced to $60 \mathrm{~min}$ at $20 \mathrm{MPa}$ and $30 \mathrm{MPa}$. In our previous study, the complete inactivation of bacteria and fungi in $\mathrm{SC}-\mathrm{CO}_{2}$ treated oil palm fruits was obtained at $10 \mathrm{MPa}, 80^{\circ} \mathrm{C}$ and 60 min (Mohd Omar et al., 2017). Time required for the complete inactivation of Bacillus spp. was 75 min under similar pressure and temperature, this happened probably due to the variation of sample size ( $20 \mathrm{~g}$ vs. $2 \mathrm{~kg}$ ) and reactor volume.

The inactivation trend was found almost similar in the case of the Aspergillus spp. inactivation in $\mathrm{OP}-\mathrm{FFB}$ using $\mathrm{SC}-\mathrm{CO}_{2}$ (Figure 3). The fungi were being rapidly inactivated after $15 \mathrm{~min} \mathrm{SC}-\mathrm{CO}_{2}$ exposure with viability reduction rate of the cells until all the cells became non-viable after $60 \mathrm{~min}$ SC$\mathrm{CO}_{2}$ exposure at $10 \mathrm{MPa}$ and $80^{\circ} \mathrm{C}$. Almost similar characteristics were exhibited in a previous study in the case of inactivation of Bacillus spp. in palm fruit fibre (Nik Norulaini et al., 2008). Nik Norulaini et al. (2008) observed an absence of colonies after formation in the treated palm fruit fibre using SC$\mathrm{CO}_{2}$ at $50^{\circ} \mathrm{C}$ and $20.7 \mathrm{MPa}$. Meanwhile, Hossain et al. (2016a) obtained a complete inactivation of Bacillus spp. in clinical solid waste using $\mathrm{SC}-\mathrm{CO}_{2}$ at $10 \mathrm{MPa}$ and $80^{\circ} \mathrm{C}$ for $60 \mathrm{~min}$. Efaq et al. (2017) gained the complete inactivation of Aspergillus spp. in clinical waste using $\mathrm{SC}-\mathrm{CO}_{2}$ at $35 \mathrm{MPa}, 75^{\circ} \mathrm{C}$ for $90 \mathrm{~min}$. The complete inactivation of the microorganisms gained in the present study at relatively lower pressure and temperature might be due to the presence of higher moisture content in OP-FFB.

The irreversible inactivation of bacterial and fungal spores in food products should be confirmed for safe consumption. Studies reported that SC$\mathrm{CO}_{2}$ inactivates the microorganisms. The $\mathrm{SC}-\mathrm{CO}_{2}$ pressure damaged the cell walls physically and the 
extracts cytoplasm materials chemically (Hossain et al., 2016b; 2013). Efaq et al. (2017) reported that the SC- $\mathrm{CO}_{2}$ inactivate Aspergillus spp. spores in clinical waste by damaging crust, outer coat and inner coats and the membrane. The $\mathrm{CO}_{2}$ was able to kill the fungi spores by penetrating the spores, causing the wall damages and spore burst. The effect of $\mathrm{SC}-\mathrm{CO}_{2}$ sterilisation treatment to the bacteria was reported by Hossain et al. (2016a). The scanning electron micrographs of SC-CO ${ }_{2}$ treated Bacillus spp. showed broken cells walls, exposure of cells, cell rupture, cell distortion, punctured holes and loss of the membrane. Microbial cell death can possibly be caused by the application of pressure as it can increase the internal pressure, and when followed by subsequent depressurisation, can interrupt the cellular structure and extraction of cell wall lipids and rupture the microbial cell wall. The sterilisation time found in the present study (60-90 $\mathrm{min})$ is in line with the conventional steam sterilisation process of OP-FFB (70-90 min) (Vincent et al., 2014). However, the sterilisation time of OP-FFB using $\mathrm{SC}-\mathrm{CO}_{2}$ could be further reduced with addition of chemical modifiers (Dillow et al., 1999).
Analysis of the Temperature Dependence by the Arrhenius Equation

The dependence of temperature on the inactivation of Bacillus spp. and Aspergillus spp. in OP-FFB subjected to $\mathrm{SC}-\mathrm{CO}_{2}$ pressure $(10 \mathrm{MPa}$, $20 \mathrm{MPa}$ and $30 \mathrm{MPa}$ ) was determined using the following equations (Hossain et al., 2013; Kim et al., 2007).

$$
\begin{array}{ll}
k=a \cdot e^{\frac{\frac{-E}{R T}}{R T}} & \text { Equation (3) } \\
\ln k=\ln a+\left(\frac{-E}{R}\right)\left(\frac{1}{T}\right) & \text { Equation (4) }
\end{array}
$$

where $k$ is the inactivation rate $\left(\mathrm{min}^{-1}\right)$ of Bacillus spp. and Aspergillus spp. in $\mathrm{SC}-\mathrm{CO}_{2}$ sterilised OP-FFB, $a$ is the pre exponential factor $\left(\mathrm{min}^{-1}\right), E$ is the activation energy $\left(\mathrm{kJ} \mathrm{mol}^{-1}\right), T$ is the absolute temperature and $R$ is the molar gas constant (8.314 $\mathrm{J} \mathrm{mol}^{-1} \mathrm{~K}^{-1}$. The activation energy $\left(E_{n}\right)$ defines the sensitivity of Bacillus spp. and Aspergillus spp. to the $\mathrm{SC}-\mathrm{CO}_{2}$ sterilisation. The temperature-dependent inactivation rate $(k)$ was determined by the Arrhenius

(a)

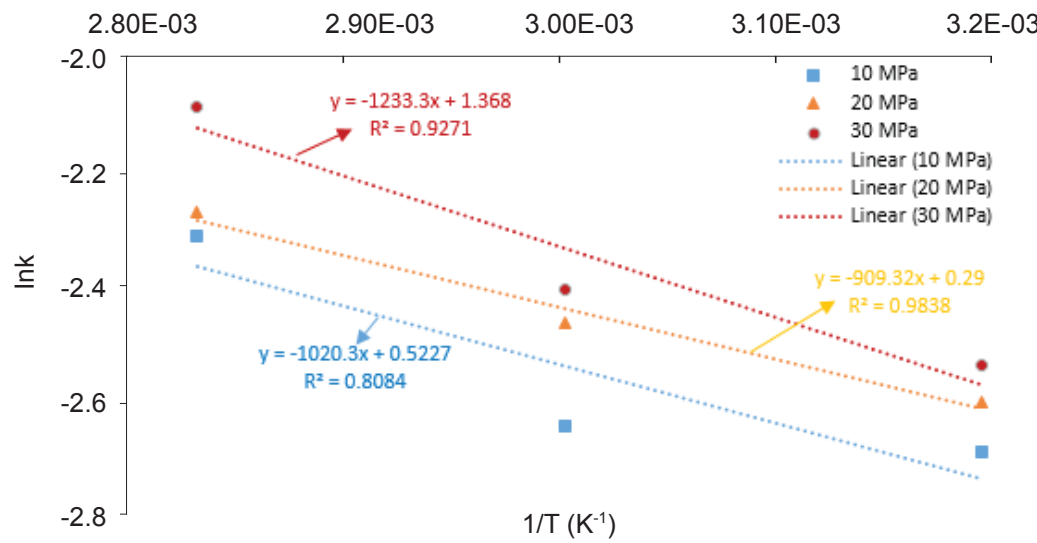

(b)

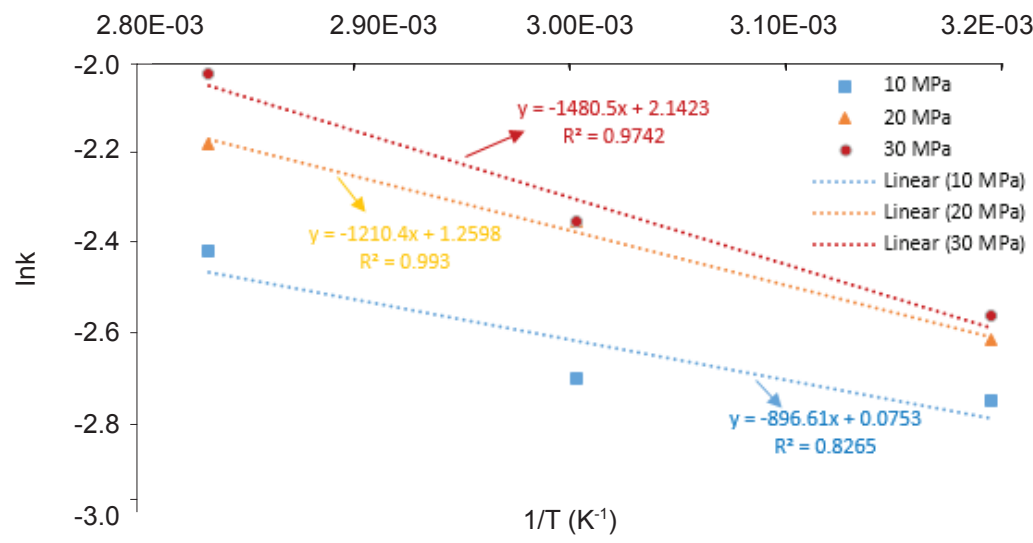

Figure 4. Determination of temperature dependence on the inactivation of Bacillus spp. (a) and Aspergillus spp. (b) in oil palm fresh fruit bunch (OP-FFB) using supercritical carbon dioxide $\left(\mathrm{SC}^{\left.-\mathrm{CO}_{2}\right)}\right.$ at pressure of $10 \mathrm{MPa}-30 \mathrm{MPa}$. 
plot for the inactivation of Bacillus spp. and Aspergillus spp. in OP-FFB subjected to SC-CO 2 pressure $10 \mathrm{MPa}$ to $30 \mathrm{MPa}$, is shown in Figure 4. The linear regression curves shown in Figure 4 reveal the $E$ values for the inactivation of Bacillus spp. and Aspergillus spp. increased with increasing pressure. The $E_{a}$ values were determined to be $7.56 \mathrm{~kJ} \mathrm{~mol}^{-1}, 8.48 \mathrm{~kJ} \mathrm{~mol}^{-1}$ and $10.23 \mathrm{~kJ} \mathrm{~mol}^{-1}$ for the inactivation of Bacillus spp.; $7.54 \mathrm{~kJ} \mathrm{~mol}^{-1}, 10.1 \mathrm{~kJ} \mathrm{~mol}^{-1}$ and $12.1 \mathrm{~kJ} \mathrm{~mol}^{-1}$ for the inactivation of Aspergillus spp. in OP-FFB at $\mathrm{SC}-\mathrm{CO}_{2}$ pressure $10 \mathrm{MPa}, 20 \mathrm{MPa}$ and $30 \mathrm{MPa}$, respectively.

The activation energy $\left(E_{a}\right)$ value for the microbial inactivation depends on types of microorganisms, sterilisation methods and variations of sample and range of temperature studied (Hossain et al., 2016a; Kim et al., 2007). The highest activation energy ( $\left.E_{a}\right)$ values obtained in the present study were $10.3 \mathrm{~kJ}$ $\mathrm{mol}^{-1}$ and $12.3 \mathrm{~kJ} \mathrm{~mol}^{-1}$ at pressure of $30 \mathrm{MPa}$ for the inactivation of Bacillus spp. and Aspergillus spp., respectively. Hossain et al. (2016a) obtained the $E_{a}$ value of $11.64 \mathrm{~kJ} \mathrm{~mol}^{-1}$ for the inactivation of Bacillus spp. in SC-CO treated clinical solid waste at pressure of $10 \mathrm{MPa}$, which is almost similar to the finding of the present study. However, the determined $E_{a}$ values in the present study were much lower than $E_{a}$ values reported Liao et al. (2007) and Kim et al. (2007). Liao et al. (2007) obtained the $E_{a}$ value of 20.6 $\mathrm{kJ} \mathrm{mol}^{-1}$ for the inactivation of Salmonella typhimurium in $\mathrm{SC}-\mathrm{CO}_{2}$ treated carrot juice at pressure of $10 \mathrm{MPa}$. Kim et al. (2007) obtained the $E_{a}$ value of $110 \mathrm{~kJ}$ $\mathrm{mol}^{-1}$ for the inactivation of Escherichia coli (E. coli) in $\mathrm{SC}-\mathrm{CO}_{2}$ treated physiological saline. Hossain et al. (2016a) obtained the $E_{a}$ value of $155 \mathrm{~kJ} \mathrm{~mol}^{-1}$ in steam autoclaved clinical solid waste. Shuler and Kargi (2002) determined the $E_{a}$ value of $532 \mathrm{~kJ} \mathrm{~mol}^{-1}$ for the thermally sterilised E. coli. Thus, it can be postulated that $\mathrm{SC}-\mathrm{CO}_{2}$ is a semi-thermal sterilisation technology, as it requires minimal energy compared to thermal sterilisation method. Although, temperature is an important variable in $\mathrm{SC}-\mathrm{CO}_{2}$ sterilisation technology for the inactivation of microorganisms, but it is not as important as for thermal sterilisation methods (Hossain et al., 2016a).

\section{Morphological Alteration of Sterilised OP-FFB}

Figure 5 displays untreated (Figure 5a) and SC$\mathrm{CO}_{2}$ treated (Figure $5 b$ ) oil palm spikelet images. As can be seen in Figure 5, the $\mathrm{SC}-\mathrm{CO}_{2}$ treatment changed the colour of the oil palm spikelet (Figure $5 b$ ). Traces of palm oil can be seen on the $\mathrm{SC}-\mathrm{CO}_{2}$ treated oil palm fruit surfaces, probably due to the softening the oil palm fruits by the $\mathrm{SC}-\mathrm{CO}_{2}$. The SEM images of the oil palm fruit fibre surface are illustrated in Figure 6.

The oil palm fruit surface image before treatment (Figure 6a) shows a clean surface without any signs of oil compared to the images after autoclaved (Figure $6 b$ ) and SC-CO treatments (Figure $6 c$ ), which display oil presence on the surface. Steam autoclaved palm fruits show uneven sterilisation on the surface. Certain parts of the fruits fibre surface were damaged and swollen which might be due to the steam absorption and effect from the high temperature. Meanwhile, the SC- $\mathrm{CO}_{2}$ treated palm fruit surfaces remained intact with oil leaching uniformly. The SC$\mathrm{CO}_{2}$ is being treated as mild sterilisation technology and widely utilised in food industry to sterilise heat sensitive food products (Hossain et al., 2016b; Kim et al., 2007; Hu et al., 2013). The SEM analyses showed that the morphology and surface appearance of the $\mathrm{SC}-\mathrm{CO}_{2}$ treated oil palm fruits are not altered or damaged (Figure 6). Further, the SEM image of the $\mathrm{SC}-\mathrm{CO}_{2}$ treated fruit surfaces revealed minimal oil leaching compared to the steam autoclaved oil palm fruits. Thus, the application $\mathrm{SC}-\mathrm{CO}_{2}$ sterilisation technology in the OP-FFB sterilisation would minimise oil loss in the palm oil industry.

One of the major shortcomings of the steam sterilisation method of OP-FFB sterilisation is the generation of the huge amount of POME (Benoit Constant et al., 2017; Mohd Omar et al., 2018).
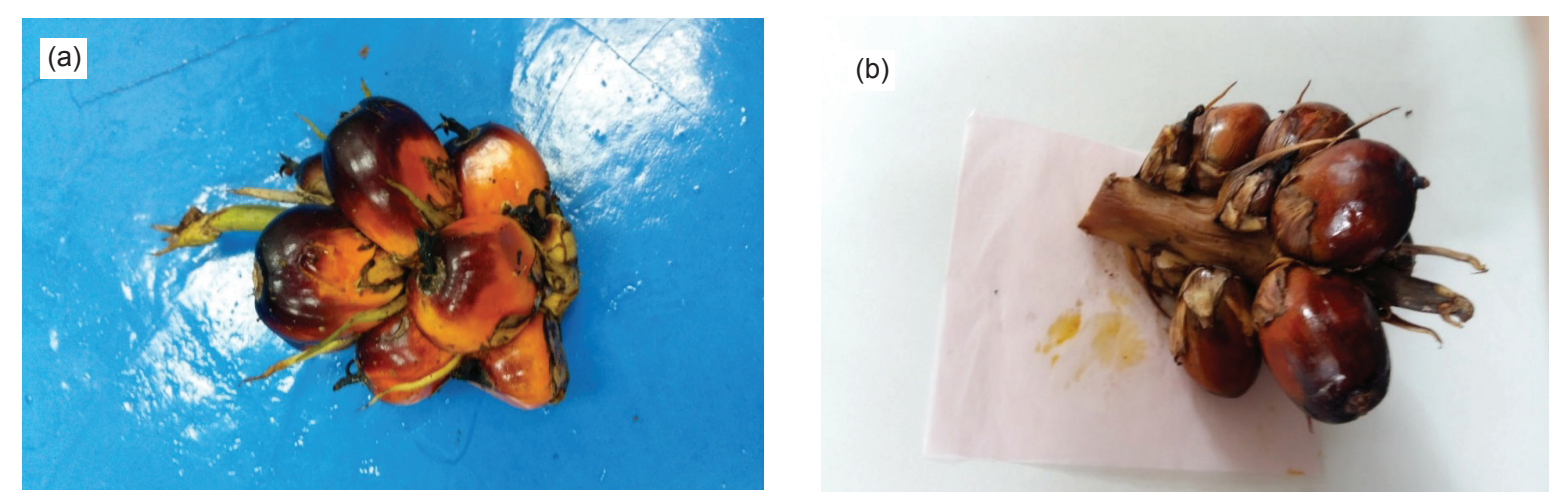

Figure 5. (a) Raw oil palm spikelet and (b) supercritical carbon dioxide (SC-CO ${ }_{2}$ treated oil palm spikelet at $80^{\circ} \mathrm{C}, 10 \mathrm{MPa}, 60 \mathrm{~min}$. 
Figure 7 shows the simplified process flow diagram of OP-FFB sterilisation using steam sterilisation method currently practiced by palm oil mills (a) and proposed supercritical sterilisation (b). It can be observed that steam steriliser uses a lot of steam and produces huge amount of POME amounting to
$62.5 \mathrm{~kg} / 100 \mathrm{~kg}$ FFB. The amount of CPO obtained is about $22.5 \mathrm{~kg} / 100 \mathrm{~kg}$ FFB. The mass balance of the palm oil production is almost similar as reported by other researchers (Ohimain et al., 2013). In comparison with supercritical sterilisation $\left(\mathrm{SC}-\mathrm{CO}_{2}\right)$, no water was involved in the sterilisation process
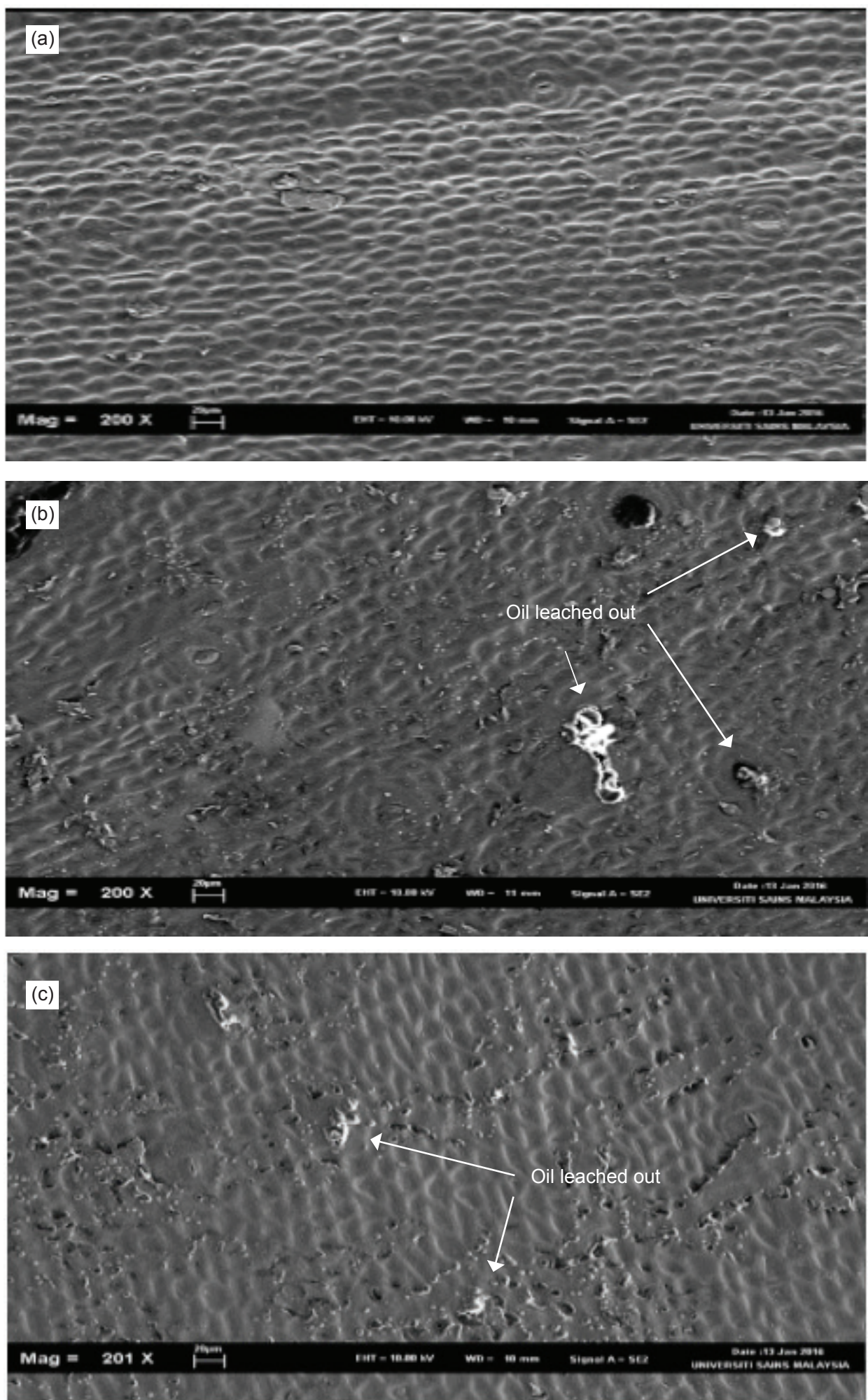

Figure 6. Scanning electron microscopy (SEM) images of treated and untreated oil palm fruit surface (a) untreated oil palm fruits, $(b)$ steam autoclave treated oil palm fruits at $0.1 \mathrm{MPa}, 121^{\circ} \mathrm{C}, 60$ min and (c) SC-CO treated oil palm fruits at $10 \mathrm{MPa}, 80^{\circ} \mathrm{C}, 60 \mathrm{~min}$. 
(a)

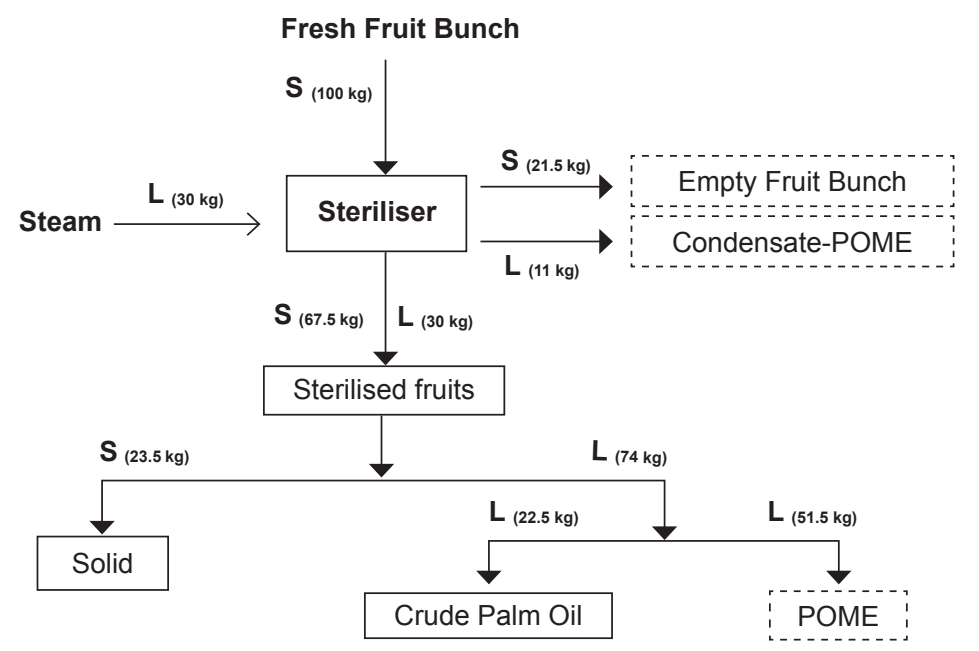

(b)

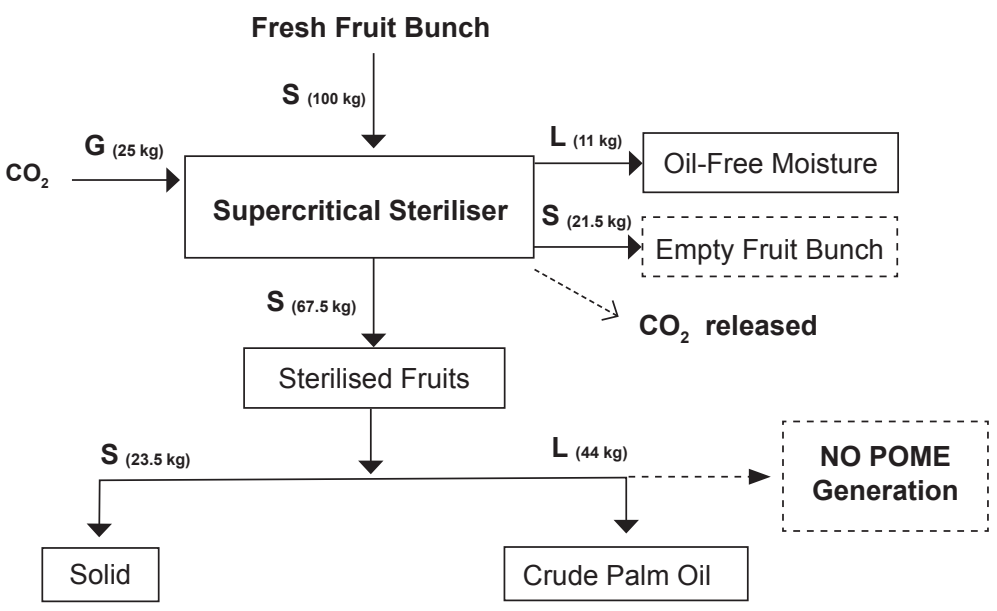

Note: Main waste streams in bold, all percentages on wet FFB basis, S - Solid, L - Liquid.

Figure 7. Simplified process flow diagram of an oil palm mill using (a) steam sterilisation and (b) supercritical sterilisation.

but it was replaced by $25 \mathrm{~kg}$ of $\mathrm{CO}_{2}$ of which $95 \%$ can be recycled and reused. More CPO is expected to be produced by using this technology with zero generation of POME. The SC- $\mathrm{CO}_{2}$ is considered more efficient in preparing the fruits for the oil extraction process without generating any wastewater.

\section{CONCLUSION AND RECOMMENDATION}

Sterilisation of OP-FFB using SC-CO technology revealed that the inactivation of Bacillus spp. and Aspergillus spp. in OP-FFB depends on pressure, temperature and treatment time. The log reduction of the both microorganisms increased with increasing pressure and temperature and treatment time. The treatment time required for the complete inactivation of Bacillus spp. and Aspergillus spp. were $75 \mathrm{~min}$ and $60 \mathrm{~min}$, respectively, at $10 \mathrm{MPa}$, $80^{\circ} \mathrm{C}$. With an increase of pressure and under the similar $\mathrm{SC}-\mathrm{CO}_{2}$ temperature $\left(80^{\circ} \mathrm{C}\right)$ the treatment time further reduced to $60 \mathrm{~min}$ and $45 \mathrm{~min}$ at $30 \mathrm{MPa}$ for the inactivation of Bacillus spp. and Aspergillus spp. in OP-FFB, respectively. The maximum activation energy $\left(E_{a}\right)$ values were determined to be $10.2 \mathrm{~kJ} \mathrm{~mol}^{-1}$ and $12.1 \mathrm{~kJ} \mathrm{~mol}^{-1}$ for the inactivation of Bacillus spp. and Aspergillus spp., respectively, which is much lower than steam sterilisation process. The analyses of SEM images revealed minimal oil leaching from the $\mathrm{SC}-\mathrm{CO}_{2}$ treated oil palm fruit. Overall, it can be concluded that $\mathrm{SC}-\mathrm{CO}_{2}$ sterilisation technology has great potential to be utilised for OP-FFB sterilisation. The application of SC-CO $\mathrm{CO}_{2}$ in OP-FFB sterilisation would benefit the palm oil industry in many ways including eliminating lipase producing microorganisms, minimise palm oil loss and no POME generation. Moreover, the non-chemical and environmentalfriendly characteristics of this treatment give an extra value to this novel method. 


\section{ACKNOWLEDGEMENT}

The authors would like to thank the Research and Innovation Division, Universiti Sains Malaysia for providing research university grant, No. 1001/RUIPTEKIND/ 8011056 as a financial support.

\section{REFERENCES}

Abdul Hadi, N M; Mei Han, N; Yuen May, C and Ah Ngan, M (2012). Dry heating of palm fruits: Effect on selected parameters. Am. J. Eng. Appl. Sci., 5: 128-131.

Balaban, M O; Arreola, A G; Marshall, M; Peplow, A; Wei, C I and Cornell, J (1991). Inactivation of pectinesterase in orange juice by supercritical carbon dioxide. J. Food Sci., 56: 743-746.

Balestrini, J L; Liu, A; Gard, A L; Huie, J; Blatt, K M S; Schwan, J; Zhao, L; Broekelmann, T J; Mecham, R P; Wilcox, E C and Niklason, L E (2016). Sterilisation of lung matrices by supercritical carbon dioxide. Tissue Engineering: Part C, 22: 260-269.

Banani, R; Youssef, S; Bezzarga, M and Abderrabba, M (2015). Waste frying oil with high levels of free fatty acids as one of the prominent sources of biodiesel production. J. Mater. Environ. Sci., 6(4): 1178-1185.

Benoit Constant, L L N; Godswill, N N; Frank, N E G; Hermine, N B; Achille, N and Martin, B J A (2017). Review of main factors affecting palm oil acidity within the smallholder oil palm (Elaeis guineensis Jacq.) sector in Cameroon. African J. Food Sci., 11(9): 296-301.

Choong, Y Y; Chou, K W and Norli, I (2018). Strategies for improving biogas production of palm oil mill effluent (POME) anaerobic digestion: A critical review. Rene. Sust. Energ. Rev., 82: 2993-3006.

Dillow, A K; Dehghani, F; Hrkach, J S; Foster, N R and Langer, R (1999). Bacterial inactivation by using near and supercritical carbon dioxide. Bacterial inactivation by using near and supercritical carbon dioxide. Proc. Natl. Acad. Sci. USA, 96: 10344-10348.

Efaq, A; Nik Norulaini, N A; Nagao, H; Al-Gheethi, A and B Kadir, M (2017). Inactivation of Aspergillus spores in clinical wastes by supercritical carbon dioxide. Arab J. Scie. Eng., 42: 39-51.

Hossain, M S; Balakrishnan, V; Nik Norulaini, N A; Rajion, Z A and Mohd Omar, A K (2013). Modeling the inactivation of Staphylococcus aureus and Serratia marcescens in clinical solid waste using supercritical fluid carbon dioxide. J. Sup. Fluid, 83: 47-56.
Hossain, M S; Nik Norulaini, N A; Banana, A A; Mohd Zulkhairi, A R; Ahmad Naim, A Y and Mohd Omar, A K (2016a). Modeling the supercritical carbon dioxide inactivation of Staphylococcus aureus, Escherichia coli and Bacillus subtilis in human body fluids clinical waste. Chem. Eng. J., 296: 173-181.

Hossain, M S; Norulaini, N A N; Naim, A Y A; Zulkhairi, A R M; Bennama, M M and Omar, A K M (2016b). Utilisation of the supercritical carbon dioxide extraction technology for the production of deoiled palm kernel cake. J. $\mathrm{CO}_{2}$ Utilisation, 16: 121129.

Hossain, M S; Nik Norulaini, N A; Balakrishnan, V; Alkarkhi, A; Rajion, Z A and Omar, A K M (2015a). Optimising supercritical carbon dioxide in the inactivation of bacteria in clinical solid waste by using response surface methodology. Waste Manage., 38: 462-473.

Hossain, M S; Nik Norulaini, N A; Balakrishnan, V; Rajion, Z A and Mohd Omar, A K (2015b). Mathematical modeling of Enterococcus faecalis, Escherichia coli and Bacillus sphaericus inactivation in infectious clinical solid waste by using steam autoclaving and supercritical fluid carbon dioxide sterilisation. Chem. Eng. J., 267: 221-234.

Hossain, M S; Balakrishnan, V; Nik Norulaini, N A; Sarker, M Z I and Mohd Omar, A K (2012). Treatment of clinical solid waste using a steam autoclave as a possible alternative technology to incineration. Int. J. Env. Res. and Public Health, 9(3): 855-867.

Hossain, M S; Santhanam, A; Nik Norulaini, N A and Mohd Omar, A K (2011). Clinical solid waste management practices and its impact on human health and environment - A review. Waste Manage., 31: 754-766.

Hu, W; Zhou, L; Xu, Z; Zhang, Y and Liao, X (2013). Enzyme inactivation in food processing using high pressure carbon dioxide technology. Cr. Rev. Food Sci. Nutri., 53: 145-161.

Junaidah, M J; Norizzah, A R; Zaliha, O and Mohamad, S (2015). Optimisation of sterilisation process for oil palm fresh fruit bunch at different ripeness. Int. Food Res. J., 22(1): 275-282.

Khan, S H; Muhammad, F; Idrees, M; Shafique, M; Hussain, I and Farooq, M H (2005). Some studieson spoilage fungi of pickles. J. Agri. Social Sci., 1(1): 1813-2235.

Kim, S R; Rhee, M S; Kim, B C; Lee, H and Kim, K $H$ (2007). Modeling of the inactivation of Salmonella typhimurium by supercritical carbon dioxide in 
physiological saline and phosphate-buffered saline. J. Microbiol Method, 70: 132-141.

Lai, O M; Tan, C and Akoh, C (2012). Palm Oil: Production, Processing, Characterisation and Uses. Elsevier Science. 852 pp.

Liao, H; Hu, X; Liao, X; Chen, F and Wu, J (2007). Inactivation of Escherichia coli inoculated into cloudy apple juice exposed to dense phase carbon dioxide. Int. J. Food Microbiol., 118: 126-131.

Liu, Q; Zhang, M; Xu, B; Fang, Z and Zheng, D (2015). Effect of radio frequency heating on the sterilization and product quality of vacuum packaged Caixin. Food Bioprod. Process, 95: 47-54.

Man, Y B C; Liu, J L; Jamilah, B and Rahman, R A (1999). Quality changes of refined-bleacheddeodorised (RBD) palm olein, soybean oil and their blends during deep-fat frying. J. Food Lipid, 6: 181193.

Mohd Omar, A K; Tengku Norsalwani, T L; Abdul Khalil, H P S; Nagao, H; Zuknik, M H; Hossain, M S and Nik Norulaini, N A (2017). Waterless sterilisation of oil palm fruitlets using supercritical carbon dioxide. J. Sup. Fluid, 126: 65-71.

Mohd Omar, A K; Tengku Norsalwani, T L; Asmah, M S; Badrulhisham, Z Y; Easa, A M; Omar, F M; Hossain, M S; Zuknik, M H and Nik Norulaini, N A (2018). Implementation of the supercritical carbon dioxide technology in oil palm fresh fruits bunch sterilisation: A review. J. CO, Utilisation, 25: 205-215.

Nanssou Kouteu, P A; Baréa, B; Barouh, N; Blin, J and Villeneuve, P (2016). Lipase activity of tropical oilseed plants for ethyl biodiesel synthesis and their typo- and regioselectivity. J. Agri Food Chem., 64: 8838-8847.

Ngando Ebongue, G F; Dhouib, R; Carrière, F; Amvam Zollo, P H and Arondel, V (2006). Assaying lipase activity from oil palm fruit (Elaeis guineensis Jacq.) mesocarp. Plant Physiol. Biochem., 44: 611-617.

Nik Norulaini, N A; Ahmad, A; Omar, F M; Banana, A A S; Md Zaidul, I S and Ab Kadir, M O (2008).
Sterilisation and extraction of palm oil from screw pressed palm fruit fiber using supercritical carbon dioxide. Sep. Purif. Technol., 60: 272-277.

Ohimain, E I; Izah, S C and Fawari, A D (2013). Quality assessment of crude palm oil produced by semi-mechanised processor in Bayelsa State, Nigeria. Discourse J. Agri Food Sci, 1: 171-181.

Patil, K J; Chopda, M Z and Mahajan, R T (2011). Lipase biodiversity. Ind. J. Sci. Technol, 4(8): 971-982.

Sanders, E R (2012). Aseptic laboratory techniques: Plating methods. J. Visualized Experiments, 63: e3064. DOI:10.3791/3064.

Sarah, M and Taib, M R (2013). Microwave sterilisation of oil palm fruits: Effect of power, temperature and D-value on oil quality. J. Medical Bioeng, 2: 153-156.

Splimbergo, S; Dehghani, F; Alberto, B and Foster, $\mathrm{N} R$ (2003). Inactivation of bacteria and spores by pulse electric field and high pressure $\mathrm{CO}_{2}$ at low temperature. Biotechnol Bioeng, 82: 118-125.

Shuler, M L and Kargi, F (2002). Bioprocess Engineering: Basic Concepts. Prentice Hall, New Jersey, USA. 576 pp.

Tagoe, S M A; Dickinson, M J and Apetorgbor, M M (2012). Factors influencing quality of palm oil produced at the cottage industry level in Ghana. Int. Food Res. J., 19: 271-278.

Taher, H; Al-Zuhair, S; Al-Marzouqi, A H; Haik, $Y$ and Farid, M M (2011). A review of enzymatic transesterification of microalgal oil-based biodiesel using supercritical technology. Enzym Res., 2011: $1-25$.

Vincent, C J; Shamsudin, R and Baharuddin, A S (2014). Pre-treatment of oil palm fruits: A review. J. Food Eng., 143: 123-131.

Wimmer, Z and Zarevúcka, M (2010). A review on the effects of supercritical carbon dioxide on enzyme activity. Int. J. Molecular Sci., 11: 233-253. 